\title{
Schumpeter, Neo-Schumpeterianism, and Stra.Tech.Man Evolution of the Firm
}

\author{
Dimos Chatzinikolaou (Corresponding author) \\ Department of Economics, Democritus University of Thrace \\ PO Box 69100, Komotini, Greece \\ Tel: 30-253-103-9824Ｅ-mail: dimos.chatzinikolaou@gmail.com \\ Charis Vlados \\ Department of Economics, Democritus University of Thrace \\ PO Box 69100, Komotini, Greece \\ Tel: 30-253-103-9824 E-mail: vlad.coop@gmail.com
}

Received: October 20, 2019 Accepted: December 19, 2019 Published: December 22, 2019

doi:10.5296/ieb.v5i2.16097ＵRL: https://doi.org/10.5296/ieb.v5i2.16097

\begin{abstract}
The Schumpeterian way of thinking for the analysis of innovation, as an evolutionary socioeconomic phenomenon, seems to be still of particular usefulness while the fundamental contribution by Nelson and Winter with the "evolutionary theory of economic change" is nowadays one of the most widely cited references in the contexts of "neo-Schumpeterianism." In a similar evolutionary concern, Vlados (2004) also examines the "dynamics of the triangle of strategy, technology, and management" (Stra.Tech.Man synthesis). The aim of this article is, in particular, to find out to what extent the Stra.Tech.Man approach utilizes and enriches some of the fundamental neo-Schumpeterian contributions by focusing mostly on the evolutionary theory of the firm, the use of evolutionary biology on analyzing socioeconomic phenomena, and the interpretation of structural change into the context of global dynamics. To achieve this goal, we first distinguish some of the criteria/filters that allow for evaluating whether a research contribution can be of neo-Schumpeterian direction. These criteria also help to identify generic concepts of recent neo-Schumpeterian trends in order to formulate a new analytical background based on the Stra.Tech.Man approach.
\end{abstract}

Keywords: Schumpeter, Neo-Schumpeterianism, Evolutionary Economics, Evolutionary 
firm theory, Stra.Tech.Man approach, Global dynamics

\section{Introduction}

Joseph Schumpeter is undoubtedly one of the most significant theoretical pioneers in the study of the socioeconomic phenomenon of entrepreneurial innovation. Schumpeter, of course, not only analyzed the entrepreneurial innovation but also presented the systemic interactions of the phenomenon, that is, the ways innovation is created and diffused in the socioeconomic system through an evolutionary process. According to Schumpeter (1939, p. 86), "The changes in the economic process brought about by innovation, together with all their effects, and the response to them by the economic system, we shall designate by the term Economic Evolution." Furthermore, in Freeman's (2009, p. 126) perspective, the central point of Schumpeter's work is that "capitalism can only be understood as an evolutionary process of continuous innovation and 'creative destruction'."

Today, an evolutionary line of thinking that begins and unfolds upon the "Schumpeterian" basis is the analytical category of "neo-Schumpeterianism" that, for the most part, stems from the fundamental contribution "Evolutionary theory of economic change" by Nelson and Winter (1982). One significant aspect of this neo-Schumpeterian work is the explicit use of biological analogies to describe how modern firms operate and "think" (the theory of the firm) - even though Schumpeter himself had previously doubted the biological dimension of economics.

On a similar methodological orientation, Vlados (2004) proposed that strategy, technology, and management constitute the deepest co-evolving spheres that govern the action of every socioeconomic organization. According to Vlados (2006, p. 27):

“... everything shows that we need now a new, organic, evolutionary way of understanding the modern capitalist firm. Maybe an evolutionary analytical organ that perceives strategy, technology, and management that every firm has, as an unbreakable evolutionary system -according to the terminology we introduce, the dynamic Stra.Tech.Man triangle- having as a constant goal the effective innovation, survival, and development of the firm."

Specifically, the "Stra.Tech.Man triangle" of the firm presupposes that the action of the socioeconomic organization follows three constant and dialectically repositioned in evolutionary terms sets of strategic, technological, and managerial questions. In particular, strategy poses the question "where is the organization, where does it want to reach, how will the organization go there, and why," technology corresponds to "how does the organization draw, create, synthesize, diffuse, and reproduce its means of work and knowledge, and why," and management corresponds to "how does the organization use its available resources and why." The Stra.Tech.Man approach suggests that these three dimensions lead the socioeconomic organization to innovation, that is, to an improvement of its competitiveness potential for survival.

Therefore, to what extent this Stra.Tech.Man approach is of neo-Schumpeterian character, and how have the Schumpeterian and neo-Schumpeterian contributions influenced its analytical scheme? What is the analytical contribution of the Stra.Tech.Man model in modern 
neo-Schumpeterian thinking? These research questions constitute the main targets of this article.

\section{Methodology}

The following steps of the article indicate the methodology we have followed to answer these research questions:

* The next section explores how the foundations and economic analysis by Schumpeter paved the way for the emergence of the subsequent stream of "neo-Schumpeterianism." The subsequent sub-section examines the neo-Schumpeterian work by Nelson and Winter by extracting some of its central points. Upon these observations, more recent neo-Schumpeterian contributions are examined next.

* After finding out recent trends in neo-Schumpeterian analysis, we present the theoretical model of the Stra.Tech.Man approach. The goal is to identify which elements of the neo-Schumpeterian analyses it uses and to what extent it enriches them.

* The final section concludes by discussing future research directions and conceptual enrichments of the Stra.Tech.Man method.

\section{Literature Review}

We can argue that Schumpeter's work is based and contributes to the analytical category of evolutionary economics. According to Nelson (2018), classical economists, long before the contributions in evolutionary biology, were the first to implement a historical perspective, being mostly "cultural evolutionary theorists." Subsequently, after the theoretical breakthrough caused by Darwin's work in the evolution of species, economists such as Veblen (1898) and Marshall (1890) emphasize that economic science is closely linked with the science of biology (and not physics). For example, Veblen (1898, p. 391) states that "The economic life history of the individual is a cumulative process of adaptation of means to ends that cumulatively change as the process goes on, both the agent and his environment being at any point the outcome of the past process" while Marshall (1890) argues that "The Mecca of the economist lies in economic biology."

The evolutionary approach by Veblen, in particular, focuses on the process of the creation of institutions, using biological analogies to describe how societies and individuals adapt in the evolution of institutions (Hodgson, 1998). On the other side, Marshall, the precursor of neoclassical economics, analyzes the dynamics of economic phenomena and their connection with economic biology. However, very often, Marshall's attempt to identify economic conditions beyond static equilibrium is disregarded (Hodgson, 1994), probably because Marshall, like Veblen, was unable to construct an integrated explanatory model of socioeconomic development through the lenses of evolutionary analysis.

\subsection{Theoretical Foundations of Schumpeter-The Schumpeterian Revolution}

The theoretical rejuvenation of evolutionary economic thinking, after Veblen and Marshall, comes mostly from Schumpeter $(1934,1939,1942)$, who places the innovative entrepreneur 
centrally by suggesting that the capitalist process bears a constant and irreversible evolutionary character. Schumpeter (1942, pp. 82-83) underlines, in particular, that "the fundamental impulse that sets and keeps the capitalist engine in motion comes from the new consumers' goods, the new methods of production or transportation, the new markets, the new forms of industrial organization that capitalist enterprise creates."

Schumpeter's work is undoubtedly multi-dimensional, and a subject of a multitude of different interpretations since it influences today's analyses in economics in various ways. According to Andersen (2009, p. 16), we can tell that Schumpeter's analytical thinking is multifarious. For example, Schumpeter's research students moved in multiple directions of economic analysis: "[Schumpeter] promoted the work of Paul Samuelson on the foundations of modern economics, Nicolas Georgescu Roegen on even more foundational issues, Ragnar Frisch on the establishment of econometrics, James Tobin on macroeconomics, Paul Sweezy on Marxian economics, and Hans Singer on development economics."

According to the general conviction of Schumpeterian scholars, Schumpeter seems to have sought to do something similar in economics to that of Darwin in biology by developing a theory that supports the study of the historical process in the evolution of economics. However, Schumpeter rejected, to a great extent, the Darwinian analogies (Hodgson, 1993; Schumpeter, 1954, p. 756), and introduced a more general evolutionary perspective upon the existing tools of neoclassical economics and the German history school (Andersen, 2009, p. xiii).

In the context of interpreting the general evolution of the capitalist system, Schumpeter perceives innovation as a development engine, which revolutionizes from within the non-static (dynamic system) of capitalism. For Schumpeter (1942, p. 31), "capitalist economy is not and cannot be stationary. Nor is it merely expanding in a steady manner. It is incessantly being revolutionized from within by new enterprise, i.e., by the intrusion of new commodities or new methods of production or new commercial opportunities into the industrial structure as it exists at any moment."

This revolutionary power of innovation is always born and reproduced by the individual, the entrepreneur's actions (Schumpeter, 1939, p. 102): "For actions which consist in carrying out innovations we reserve the term Enterprise; the individuals who carry them out we call Entrepreneurs." Schumpeter argues that there is a cyclical process in the system of evolution of capitalism, defining it as a business cycle, where innovations produce alternate phases of prosperity and recession (Schumpeter, 1939, p. 223). For Schumpeter, this cyclicality is also present in some terms that the neoclassical tradition interprets statically: for example, the credit "is essentially the creation of purchasing power for the purpose of transferring it to the entrepreneur, but not simply the transfer of existing purchasing power" (Schumpeter, 1934, $\mathrm{p}$. 107). In this sense, capitalism is an evolving economic system where innovations are made through the creation of credit and productive expansion: "capitalism is that form of private property economy in which innovations are carried out by borrowed money, which in general, though not by logical necessity, implies credit creation" (Schumpeter, 1934, p. 223).

Schumpeter (1942, p. 107) distinguishes the theoretical examination between the dominant 
static analysis of economic quantities, arguing that dynamic analysis is needed. This analysis must be able to study the succession of the phenomenon throughout history as well as to find out future expectations:

"Dynamic analysis is the analysis of sequences in time. In explaining why a certain economic quantity, for instance a price, is what we find it to be at a given moment, it takes into consideration not only the state of other quantities at the same moment, as static theory does, but also their state at preceding points of time, and the expectations about their future values."

In the Schumpeterian view of economic change, therefore, change only occurs when there are tangible and "measurable" results by realizing the particular importance of the required time for a change to be fully established and assimilated into the system (in the "economic organism" as Schumpeter mentions):

"Changes in method of production in the widest sense of the word, such as have occurred in the period following upon the post-war crisis, necessarily create disturbances in the economic organism sufficient to produce a period of adaptation or recession. Disturbances of this kind differ among each other not only in intensity but also according to the time which must elapse before the new things created take their full effect; i.e., in most cases, before the products of the new plans reach the consumer's market" (Schumpeter, 1931, p. 179).

Although Schumpeter (1942, p. 74) uses biological analogies in his analyses on several parts of his work, such as "organism" or "adaptation," he distinguishes economic science from biology and, in particular, socioeconomic evolution from biological evolution: "most methods of social selection, unlike the 'methods' of biological selection, do not guarantee performance of the selected individual." However, according to Andersen (2009, pp. 26-27), the fact that Schumpeter "was committed to both equilibrium economics and evolutionary economics" it is not by coincidence: for example, biology analyzes both the physiology of an organism and the evolutionary process that creates this organism. Schumpeter probably thought that equilibrium economics is comparable to physiology and that evolutionary economics is analogous to evolutionary biology.

In summary, it seems that Schumpeter's work has a central explanatory power in the dynamics of innovation. We feel, however, that the most critical in Schumpeter's case for the role of innovation is that the definitive cause of overall economic development is the phenomenon of "creative destruction" produced by innovation (Schumpeter, 1942, pp. 81-86). At the same time, Schumpeter's work has a robust interpretative power since it offers a profound and extensive study of the historical unfolding of economic science. For example, in his last incomplete over 1000-page "History of economic analysis," Schumpeter (1954, p. 2) attempts to interpret the "history of the intellectual efforts that men have made in order to understand economic phenomena." At the same time, in other numerous published articles, Schumpeter studies the works of economists of his day, as well as several earlier ones (for example, Schumpeter, 1941, 1946, 1949c, 1949b).

Of course, Schumpeter's work is historical and evolutionary, which the main body of 
economic theory cannot understand because it is often exhausted in fragmentary interpretations. As Schumpeter (1942, p. 82) pointed out: "The essential point to grasp is that in dealing with capitalism we are dealing with an evolutionary process. It may seem strange that anyone can fail to see so obvious a fact which moreover was long ago emphasized by Karl Marx. Yet that fragmentary analysis which yields the bulk of our propositions about the functioning of modern capitalism persistently neglects it."

Therefore, what criteria can we apply to perceive any research contribution as "Schumpeterian"? We consider the following points as guiding lines for a work to fall within the Schumpeterian analytical direction:

1) The perception of the economy as the birth of a continuous and unstoppable mixed socioeconomic evolutionary process

2) The examination of all economic phenomena in their dynamic, combinational, and historical dimensions

3) Economic evolution can be studied "penetratingly" by using biological and ecosystemic analogies

4) The entrepreneur and entrepreneurship are the primary sources of economic progress through the "revolutionary" path provided by innovation

5) The "creative destruction" is, at the same time, the mechanism of renewing the "cells" of the economic system but also of clearing out outdated forms of economic activity.

\subsection{Neo-Schumpeterian Analysis: The Significant Contribution by Nelson and Winter}

From these fundamental and sufficiently "revolutionary" findings of Schumpeter, the most recent "neo-Schumpeterian" contributions originate, usually having as a milestone (Hodgson \& Lamberg, 2018) the work by Nelson and Winter (1982).

As Nelson and Winter (1982, p. 39) argue, specifically: "The influence of Joseph Schumpeter is so pervasive in our work that it requires particular mention here. Indeed, the term 'neoSchumpeterian' would be as appropriate a designation for our entire approach as 'evolutionary'."

This work focuses primarily on issues of technological change and the firm's "routines." Nelson and Winter argue that the existence of the process of change in the economy involves an evolutionary process in which a Darwinian interpretation is legitimate. As a result, mechanisms of "natural selection," variety generation and reproduction emerge within a more general evolutionary framework of "constant change" (Douma \& Schreuder, 2017).

One of the fundamental features of Nelson and Winter's approach is the position that the neoclassical approach has, by definition, limited explanatory boundaries that lead conventional economic analysis, within this school of thought, to a theoretical impasse. They consider, in particular, that the "orthodox" interpretation of technical change is not capable of penetrating analytically into the micro-level of the firm and thus remains analytically sterile (Nelson \& Winter, 1982, p. 206): “The weakness of the theoretical structure [neoclassical 
theory] is that it provides a grossly inadequate vehicle for analyzing technical change. In particular, the orthodox formulation offers no possibility of reconciling analyses of growth undertaken at the level of the economy or the sector with what is known about the processes of technical change at the microeconomic level."

They argue that their evolutionary approach is based on understanding the "intellectual constraints associated with the treatment of firm and industry behavior that is now standard in economic theory" and that their analysis "reconciles economic analysis with the realities of firm decision making ... to improved understanding of technological change and the dynamics of the competitive process" (Nelson \& Winter, 1982, p. viii).

In the evolutionary theory of the firm by Nelson and Winter (1982, p. 4), firms do not use the maximization calculus of the orthodox economic approach while they "do not focus our analysis on hypothetical states of 'industry equilibrium,' in which all the unprofitable firms no longer are in the industry and the profitable ones are at their desired size." On the contrary, "firms are modeled as simply having, at any given time, certain capabilities and decision rules. Over time these capabilities and rules are modified as a result of both deliberate problem-solving efforts and random events. And over time, the economic analogue of natural selection operates as the market determines which firms are profitable and which are unprofitable, and tends to winnow out the latter."

At the same time, they argue that they accept biological analogies for a better understanding of economic problems, insofar as they are useful in constructing a complete economic theory (Nelson \& Winter, 1982, p. 11):

"We are pleased to exploit any idea from biology that seems helpful in the understanding of economic problems, but we are equally prepared to pass over anything that seems awkward, or to modify accepted biological theories radically in the interest of getting better economic theory."

For Nelson and Winter (1982, pp. 160-161), all firms interact with their environment, somehow as "living organisms" that exhibit specific behavioral routines. They suggest that the fitness of a firm depends on the characteristics of the environment that includes firms with similar routines; at the same time, the environment itself depends on the routines of the firms-organisms.

Another central idea of their work is that economic evolution appears dependent upon "natural trajectories" where specific technological patterns in the production of firms within industries prevail: "Natural trajectories are specific to a particular technology or broadly defined 'technological regime'." This technological regime defines ultimately the way economic relationships are performed for a given period. The "technological regime" refers in particular to "achievable capabilities, defined in the relevant economic dimensions, limited by physical, biological and other constraints, given a broadly defined way of doing things" (Nelson \& Winter, 1982, p. 258).

In conclusion, the theoretical background from which Nelson and Winter's neo-Schumpeterian approach emerges can be said to have at least three of the following 
general characteristics:

1) The mainstream neoclassical interpretation, where the firm is considered, overly simplified, an optimizer of its production function, is leading to a dead-end. The "biological routines" of the socioeconomic organization are more important as they relate the organization to its environment in a more realistic way. In this evolutionary interpretation of economic analysis, we realize that the firm has and expresses specific behavior.

2) The finding that the firm "behaves" starts from evolutionary biology, and therefore economic phenomena present biological analogies. The main economic actors, namely firms, are organisms that face an environment that varies over time based on the activity of the organisms it hosts.

3) Finally, economic evolution appears to change in a structural way when the prevailing technological regimes change. These evolutionary trajectories are formed upon generally used patterns of knowledge and technology: that is, they are "a broadly defined way of doing things."

\subsection{Neo-Schumpeterianism and Recent Trends}

But how is neo-Schumpeterianism defined besides Nelson and Winter's "evolutionary theory of economic change," and what seems to be some of its key features? Based on the above findings and from a general review of the literature, it appears that neo-Schumpeterian economics examines socioeconomic phenomena at least on three levels:

A) Neo-Schumpeterian theory places at the analytical center the evolutionary theory of the firm and business strategy

According to this interpretation of the neo-Schumpeterian approach: “... the neo-Schumpeterian theory strongly prefigures the concerns of the resource view of the firm that emerges in the strategy field years later" (Levinthal, 2006, p. 391).

Therefore, a central component of the neo-Schumpeterian perspective is also the innovative entrepreneur and the structural change ("creative destruction") that it causes in the overall socioeconomic system and, more generally, in the overall system of capitalism:

"The basic principles of neo-Schumpeterian research paradigm in economics are: Schumpeter's basic ideas about the central importance of the innovation process and its disequilibrium character; The role of the entrepreneur or the large, bureaucratic R\&D-based firm; 'Creative destruction' as the driving force behind structural change; Aggregate fluctuations at different time scales as inseparable features of the capitalist process of development" (Sledzik, 2013, p. 74).

Rahmeyer (2016) argues that in the neo-Schumpeterian evolutionary perception, firms are not only passively adapting based on their specific routines, but also displaying skills that enable them to both transform and create new resources. According to Teece (2016), conventional economic theory has mostly overlooked the role of management, unlike Schumpeter, who argued that managers, to some extent, cover the role of the entrepreneur by applying new 
combinations of resources to meet customer needs. By approaching the issue from the perspective of large organizations, it is argued that a complete interpretation of management and organizational capabilities can contribute to building more realistic economic models.

Moreover, Erixon (2016) seems to criticize the neo-Schumpeterian perspective, which argues that firms are more innovative when there are positive forces associated with creative destruction. As the author suggests, in a "neoclassical Schumpeterian" model, intense competition and low demand can cause an increase in innovation and productivity in established firms. We would add, of course, that the creative destruction itself has both negative and positive socioeconomic dynamics and consequences. For González-Loureiro, Dabic, and Cvijanović (2011), it is a fact that the neo-Schumpeterian economic analysis explains better the micro-level, while the post-Keynesian the macro level. The authors argue, in particular, that an innovation system is a "market" in which there is a point of equilibrium between supply and demand and which explains growth. The central assumption of the study is that a meso-level approach could bridge these two approaches.

However, as shown by Dopfer's (2011) study, the neo-Schumpeterian and evolutionary framework seem to be complete enough to interpret all three levels of space (micro-meso-macro). Dopfer takes into account Schumpeter's assumption that entrepreneurs innovate (micro-level), the imitators copy them (meso-level), and, as a result of this process, waves of creative destruction lead to economic development starting from within the system (macro). The central assumption is that the analytic center lies at the "bi-modal" meso-level at which different socioeconomic actors implement an idea (a "general rule" as the author calls it).

\section{B) Neo-Schumpeterian theory studies economics from a biological perspective}

One of the main features of "neo-Schumpeterianism" is its clear theoretical contiguity to evolutionary biology: "neo-Schumpeterians use a biological evolutionary analogy to show how the innovative firm evolves and this has implications for macroeconomic development" (Courvisanos \& Mackenzie, 2014, p. 56).

As the majority of neo-Schumpeterian analyses assume, economic actors interact with their environment by making decisions in which they have only limited rational limits: "Neo-Schumpeterians within the evolutionary economics camp consider the concept of selection as a core element of evolutionary economics. Selection processes, they argue, act on the diversity of behaviors and entail behavioral adaptations of agents who are only boundedly rational" (Cordes, 2014, p. 2).

Evolutionary economics, part of which is neo-Schumpeterianism, rejects the study of socioeconomic systems in terms of static equilibrium, using concepts such as "living" or "survival" of the firm (Ciote, 2011). However, these analogies are nothing but "loose analogy constructions" of the Darwinian approach to evolutionary biology (Witt, 2014). That is, neo-Schumpeterianism does not intend directly to apply the Darwinian evolution of species to firms; as, for example, Georgescu-Roegen (1971) and Boulding (1978) did with the "naturalistic"/ecological interpretation. The goal of neo-Schumpeterianism is a more 
"realistic" approach to human behavior.

However, on this issue of the biological interpretation of economic activity, there is a continuing scientific debate with opposing views. According to Hart (2013, p. 148), evolutionary economists tend to reject the Schumpeterian approach to equilibrium in conjunction with economic evolution. In evolutionary biology, of course, the rate of appearance of genes in a population can be constant over some time. As the author argues, economic science shows the strategic behavior of actors, which continually redefines the balances. Therefore, a composite interpretation of the "balance of imbalance" in Schumpeter's evolutionary thinking is not far from reality, since the analysis of static equilibrium is used only as an interpretative rather than a predictive tool:

"... in economics, behavior is strategic and reorganizes the environment in which it operates, and the conditions to be satisfied for 'equilibrium' are numerous and often intangible. Importantly, to the extent that it is used, equilibrium analysis in evolutionary theory is rarely seen as a predictive tool but rather as an aid to explanation. Economists have demanded far more from equilibrium analysis, despite the greater difficulties, than their counterparts in evolutionary biology" (Hart, 2013, p. 148).

Finally, another aspect of the neo-Schumpeterian analysis also appears in the concept of business ecosystems. In particular, the neo-Schumpeterian perspective seems to focus on how the "evolutionary economic geography" of innovation encompasses the interacting capabilities and assets of economic actors (Cooke, 2016). The founder of the modern concept of business ecosystems is Moore (1993), who has argued that in a business ecosystem, firms co-evolve their capabilities based on innovation. However, Moore in his work does not directly refer to Schumpeter's work, thus we can say that the business ecosystem concept constitutes an "external" neo-Schumpeterian analysis, although recent studies use Schumpeterian concepts in their business ecosystems analyses (Faissal Bassis \& Armellini, 2018; Gómez-Uranga, Miguel, \& Zabala-Iturriagagoitia, 2014).

A parallel concept is, of course, the "national innovation system" by neo-Schumpeterian economists (Freeman, 1995; Lundvall, 1992; Nelson, 1993), which studies how the diffusion of technology among individuals, firms, and institutions affects the innovative potential of a national system. At the same time, analytical variations and specifications of the national innovation system at local/regional or industrial level exist and are being developed (Gomes, Facin, Salerno, \& Ikenami, 2018), where the Schumpeterian innovative entrepreneur is also at the center of the system (Malecki \& Spigel, 2017).

\section{C) Structural change and economic evolution}

In this context, all levels of the socioeconomic system are taken into account as they co-evolve. For example, according to Hanusch and Pyka (2005, p. 3):

"Neo-Schumpeterian economics today is most appealing in studies of innovation and learning behavior at the micro-level of an economy, in studies of innovation-driven industry dynamics at the meso-level, and in studies of innovation determined growth and international competitiveness at the macro-level of the economy." 
Here, the institutional environment and the periodic change of the dominant paradigm in technological terms mostly are of central analytical importance: "Neo-Schumpeterianism is both supply side and demand side; it is about matching the social and institutional framework to the techno-economic paradigm" (Kaldor, 2008).

Schumpeter interpreted technology in particular as an endogenous factor that shapes the institutional and social structure (Aydin \& Takay, 2012). In this interpretation, Schumpeter added the role of innovation to social change, observing that the system of capitalism carries an endogenous "elevating" cyclicality. On this finding, several Schumpeterian analysts explore the aspect of structural change in the "techno-economic paradigm" that occurs periodically in long waves (Gutiérrez-Barbarrusa, 2019; Köhler, 2012). According to the approach of techno-economic paradigms (Dosi, 1982; Perez, 2002, 2010), there are unifying systemic waves in the unfolding of capitalism, initiated and concentrated through technological inventions or innovations.

For Bodrožić and Adler (2018), though, a paradigmatic change in the economy, from a neo-Schumpeterian perspective, is more of "micro-economic" nature, and in particular, a process that starts with the evolution of the different applied managerial, strategic and leadership models. It is argued that the waves of technological revolutions are also causing corresponding waves to the change of the dominant organizational paradigm in order to identify those actors that are causing structural change in economic evolution. On this matter, for Pyka and Nelson (2018, p. 104), neo-Schumpeterian economics is a dynamic analysis that, besides the micro and macro levels, also takes into account the intermediate, meso-level, where "the decisive structural and qualitative changes take place and can be observed."

Andreoni and Scazzieri (2014), besides, argue that Schumpeterian innovations can change the overall trajectory of the production system over time, an approach quite different from equilibrium growth modeling, where economic prosperity is examined, in most of the cases, in terms of comparative statics. In a modern (neo-Schumpeterian) approach to economic change, where "gales of creative destruction" are essentially creating new knowledge, economic development cannot be viewed statically, as people's preferences are always variable over time. According to Heinrich (2017), Schumpeter also argued that the role of the government, as well as the banking system, is crucial in creating an environment conducive to technological development caused by the creative destruction that gives room for temporarily higher profits.

Of course, one common point of reference in neo-Schumpeterian economics is the assessment that it studies complex systems in which policy proposals may be quite different from one another (Metcalfe, 2010; Robert \& Yoguel, 2016). In any case, the institutional framework is crucial for economic growth (Rahmeyer, 2010), in which evolutionary change is permanent and leads to the irreversible transformation of economic structures (Scazzieri, 2018).

In conclusion, the above three analytical levels of neo-Schumpeterianism lead us to the following conclusions regarding the contemporary trends of this evolutionary stream of thought (Figure 1): 


\section{Macrothink}

1) The neo-Schumpeterian theory of the firm places the entrepreneur's innovation at the center. However, it mainly studies larger organizations and how they implement their strategy, management, and research and development (technology) department.

2) Neo-Schumpeterian economics is evolutionary by nature and is explicitly linked to the contributions of evolutionary biology. Here, equilibrium is not a tool of prediction, in the standards set by the neoclassical maximization, but a method that helps perceive how socioeconomic actors adapt and co-transform the environment that hosts them.

3) The neo-Schumpeterian approach is, in fact, a more comprehensive interpretation of the socioeconomic system, at the various levels of space. The ontological discrimination at the micro-meso-macro level is also exploited here, taking into account the evolution of institutions and prevailing evolutionary paths in the global socioeconomic system. Innovation, which starts from the micro-firm level, causes waves of creative destruction (structural change) that periodically reshape the dominant technological paradigm.

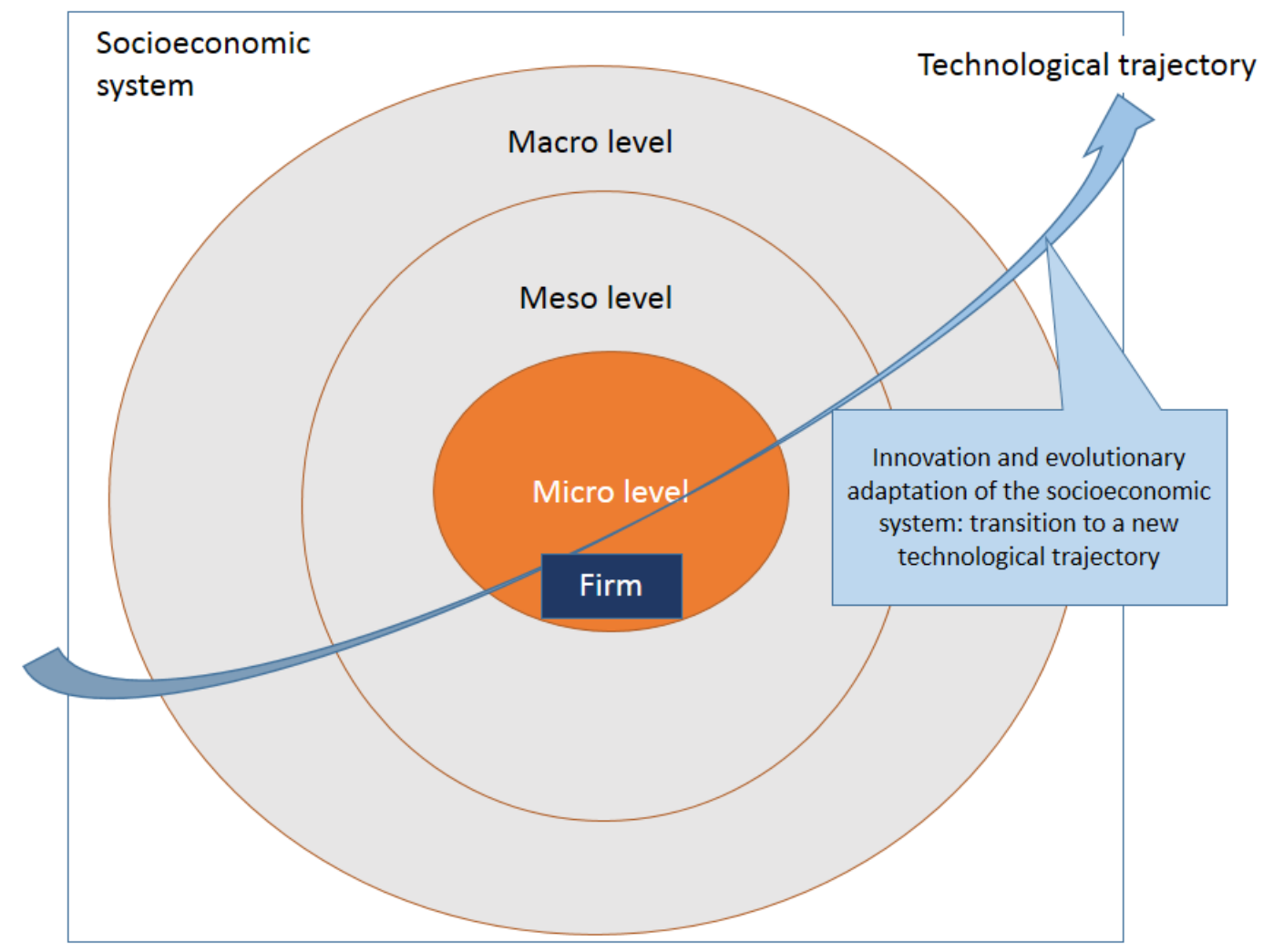

Figure 1. The socioeconomic system and the evolutionary adaptation based on the neo-Schumpeterian analysis

\section{Analytical Counterproposal: The Stra.Tech.Man Approach as a Possible Conceptual Enrichment of neo-Schumpeterian Socioeconomic Development}

One approach that seems to build upon neo-Schumpeterian contributions is the Stra.Tech.Man approach. Vlados (2004) suggests that the innovative potential of any 
socioeconomic organization always depends on the particular syntheses it hosts internally in terms of strategy, technology, and management. The central assumption of this model is that the firm responds, explicitly or implicitly, and continuously to a series of dialectical questions (Figure 2):

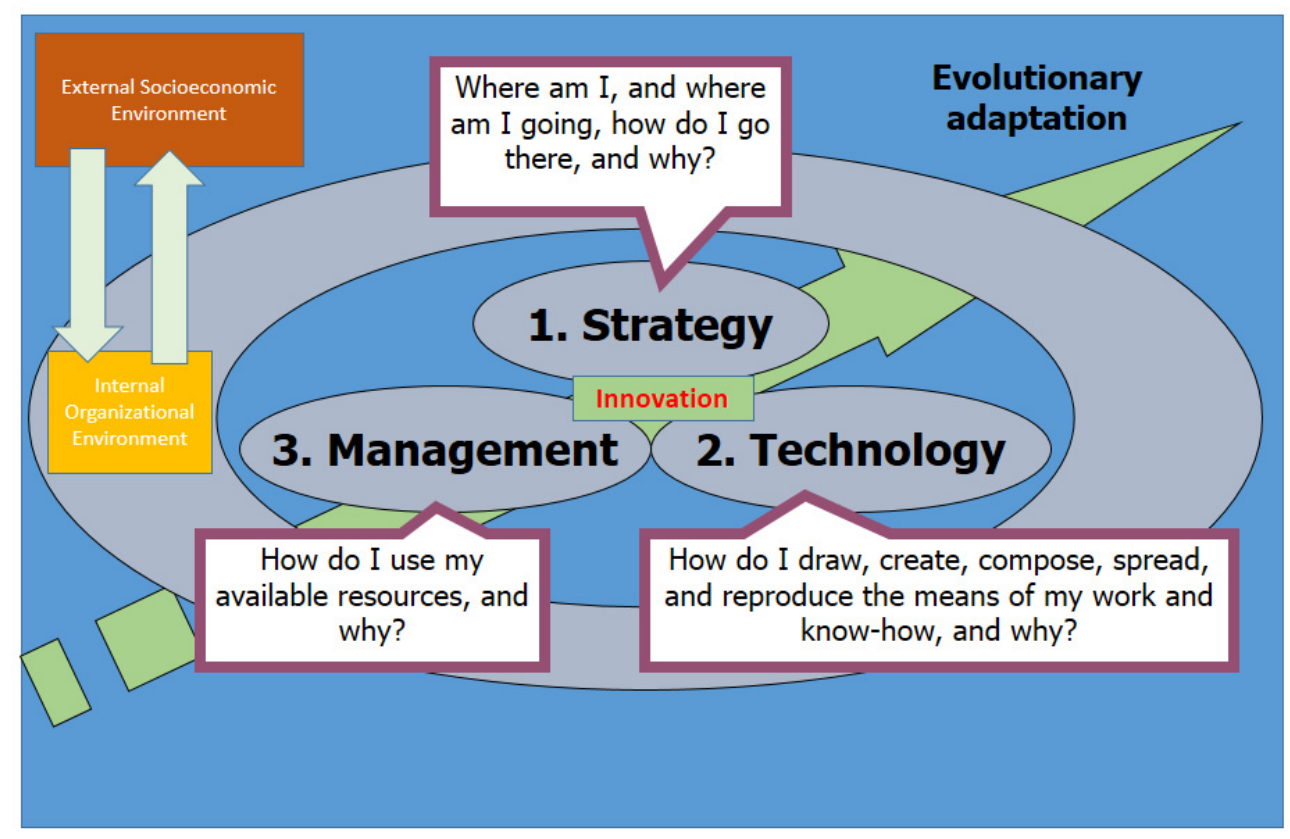

Figure 2. The Stra.Tech.Man core of the firm. Adapted from Vlados (2004)

* "Strategy: Where am I, and where am I going, how do I go there, and why?"

* "Technology: How do I draw, create, compose, spread, and reproduce the means of my work and know-how, and why?"

\section{* "Management: How do I use my available resources, and why?"}

Vlados uses this approach first during the early 2000s to identify how the Greek socioeconomic system is integrated into globalization. He proves that the majority of firms operating in Greece (and in other socioeconomic systems of similar developmental potential) exhibit a specific “Stra.Tech.Man physiology.”(Note 1).

Based on this analysis of the Greek socioeconomic system and the peculiar dynamics of entrepreneurship that host and reproduces, Vlados (2004) suggested that Greece has entered into an impending crisis of structural transformation, long before expressed in state budget terms, due to the declining competitiveness of the Greek firms. As a result, the competitive insertion of the Greek socioeconomic system in the intensively accelerating phase of globalization seemed increasingly challenging (Vlados, 2005). This declining competitiveness is accompanied necessarily by systemic interactions throughout the Greek socioeconomic system since the activity of the firm is placed at the analytical center. In this approach, the firm constitutes the profound dialectic "player" shaping with its innovative 
potential in Stra.Tech.Man terms both the industrial and national competitiveness. Moreover, these findings seem also valid during the subsequent phase of overall crisis (budgetary, debt, and trade balance crisis) of the Greek economy; a crisis that also has social apart from economic implications and characteristics: cultural and ideological (Vlados \& Chatzinikolaou, 2019c, 2019b; Vlados, Deniozos, Chatzinikolaou, \& Demertzis, 2018a).

Nowadays, the Stra.Tech.Man model and typology are still tested and implemented in the field. In a recent study, Vlados and Chatzinikolaou (2019a) study how the Stra.Tech.Man physiology of the firm evolves within a less developed regional business ecosystem by using diagnostic questionnaires at the levels of strategy, technology, and management. They use this method to find out possible shifts in the Stra.Tech.Man physiology of a sample of firms through open questionnaires of Likert-scale type. This diagnosis of the physiology of firms also indicates the competitive potential of the overall business ecosystem that hosts the activity of these firms. The main finding of this research is the ascertainment that all firms, like "living organisms," demonstrate specific, evolving through time, physiologies that set the boundaries to the potential innovation and the effective adaptation in the changes of the global environment (Note 2).

Therefore, Vlados (2004) assumes that to articulate a targeted policy to stimulate the competitiveness of the socioeconomic system requires first to diagnose the Stra.Tech.Man physiology of the firms operating internally. To this end, after diagnosing the internal environment, the overall interpretation of the successive external environment follows, which influences (and at the same time is influenced) the competitiveness of the firms. In this sense, institutions also evolve through a "Veblenian" perspective while, for some modern institutional theorists (Acemoglu \& Robinson, 2012), institutions constitute the most critical aspect of development or underdevelopment, respectively.

The process of socioeconomic change in this approach has probably a neo-Schumpeterian and evolutionary character since it takes into account all interactions at the micro-meso-macro level. Schematically, Vlados and Chatzinikolaou (2019d) argue that all these systemic interactions can take the form of a systemic "web of competitiveness" (Figure 3). 


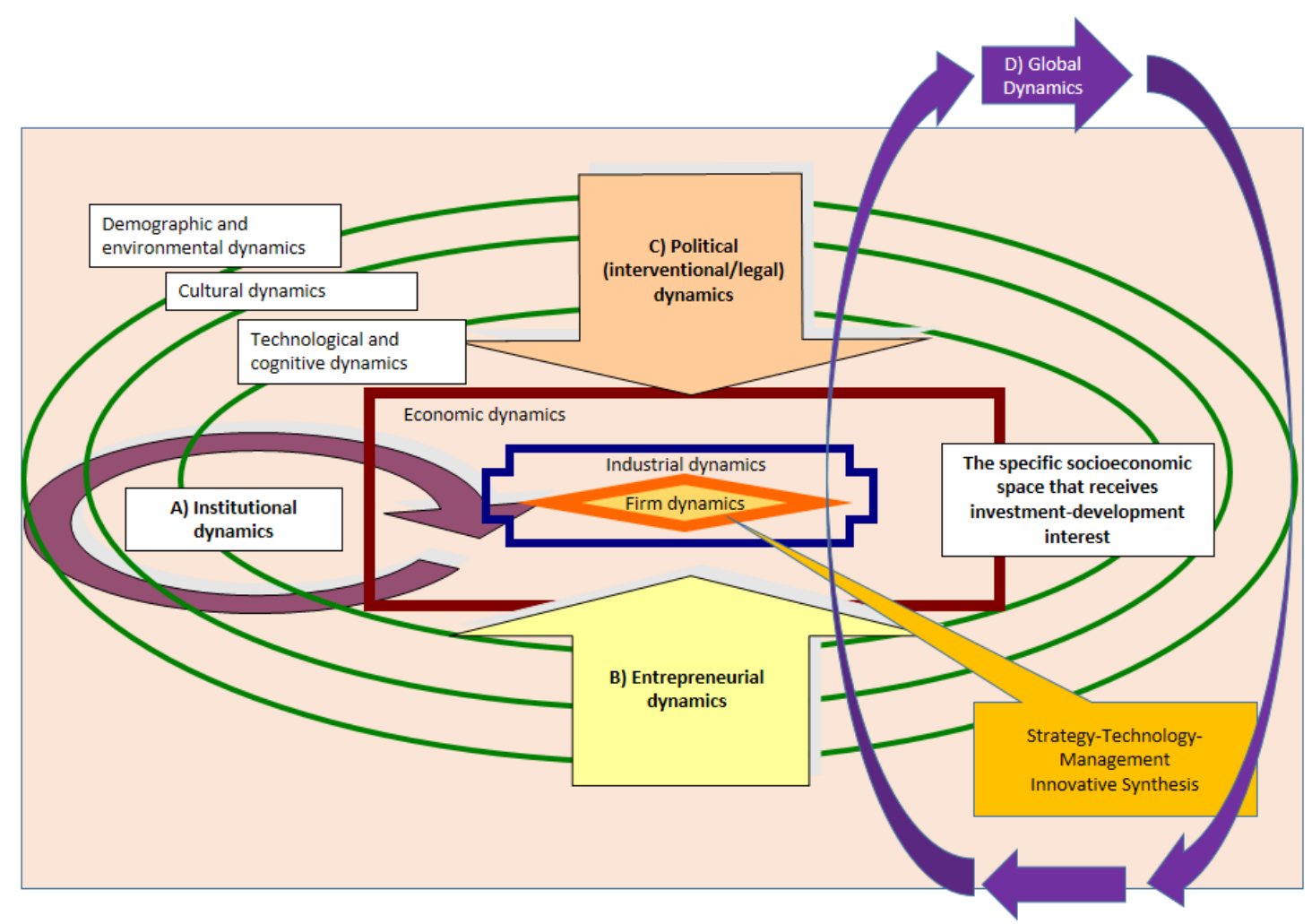

Figure 3. The "competitiveness web" and global dynamics. The firm in Stra.Tech.Man terms in the analytical epicenter of the socioeconomic system. Reproduced from Vlados and Chatzinikolaou (2019d)

In this theoretical scheme, the interpretation of socioeconomic development is distinguished in three co-evolving and successive steps:

* It starts with the innovative synthesis in Stra.Tech.Man terms executed by the firm as a socioeconomic "living organization."

* The firm, with its action, influences the surrounding industrial dynamics, which in turn "opens up" to the rest socioeconomic levels of space and time. Technological and cognitive dynamics are influenced by cultural dynamics, which in turn is a constituent of the overall demographics of the socioeconomic system.

* These co-evolving micro-meso-macro levels are influenced at the same time from three structural dynamics: from the political intervention dynamics, the overall diffusion of the innovative entrepreneurial dynamics, and from the dynamics of the institutional regime.

* The overall socioeconomic system, which is a space that receives investment interest, accepts and gives feedback to global dynamics. In today's era of crisis and restructuring of globalization (Vlados, Deniozos, \& Chatzinikolaou, 2019; Vlados, Deniozos, Chatzinikolaou, \& Demertzis, 2018b), partial socioeconomic systems ("competitiveness webs") interact with dynamic processes of co-evolution and co-determination. 


\section{Conclusions and Discussion}

The present study attempted to identify through the neo-Schumpeterian thinking the recent trends of the study of "neo-Schumpeterianism." By doing so, the goal was to end up with the analytical counterproposal of the Stra.Tech.Man approach (synthesis of strategy-technology-management) by Vlados (2004) in order to find out whether this approach constitutes an evolutionary continuation of the neo-Schumpeterian interpretation of the firm and socioeconomic development.

We distinguished at least three co-evolving levels of the neo-Schumpeterian socioeconomic analysis: a) the evolutionary theory of the firm, b) the use of biological analogies, and c) the interpretation of structural change of the socioeconomic system.

To what extent though the Stra.Tech.Man approach of the firm participates in these levels? In what point does it enrich the neo-Schumpeterian socioeconomic analysis?

\section{A) Neo-Schumpeterian theory of the firm}

The Stra.Tech.Man approach seems capable of examining all kinds of socioeconomic organizations, irrespectively of their sizes. The neo-Schumpeterian theory of the firm seems to mostly focus on the innovation of large organizations, while innovation can drastically come from smaller socioeconomic actors as well. The Stra.Tech.Man theory of the firm perceives that all socioeconomic organizations have and apply, directly or indirectly, different strategy, technology, and management in order to produce and reproduce their innovative potential.

\section{B) Neo-Schumpeterian use of evolutionary biology}

The neo-Schumpeterian analysis studies all the components of socioeconomic system from an organic rather than a mechanistic perspective. It rejects, that is, the maximization and "automatization" calculus of neoclassical origin, suggesting that all people, firms, and institutions (such as business ecosystems) adapt to their environmental conditions with dynamic processes. In this direction, the Stra.Tech.Man approach "operationalizes" and therefore enriches the "biological paradigm" in economic analysis since it recognizes particular "physiological" types of firms, which define the overall development of the socioeconomic system.

\section{C) Neo-Schumpeterian structural change and economic evolution}

The neo-Schumpeterian interpretation perceives socioeconomic space into multiple co-evolving levels in which specific technological "paradigms" prevail periodically. These paradigms shape the conditions for innovation of the economic actors within partial socioeconomic systems (local, regional, national, and global). The Stra.Tech.Man approach synthesizes interpretatively and internally the technological dimension, which seems to be analyzed in the Schumpeterian thinking from the perspective of knowledge. In the sense that technology in the Stra.Tech.Man approach expresses how to "draw, create, compose, spread, and reproduce the means of my work and know-how, and why?" it provides a practical dimension in the way the socioeconomic organizations use these cognitive dynamics. 
Moreover, with the "competitiveness web" approach, which is co-formulated together with the "cells" of the system, that is, the firms in Stra.Tech.Man terms, a better-integrated interpretation of structural change seems to be attained. This assumption seems to be valid since the diagnosis of the Stra.Tech.Man physiology has interpretative power to describe the changes in the competitiveness of the different socioeconomic systems since it initiates analytically from the socioeconomic organizations internally.

Consequently, to the question of whether the Stra.Tech.Man approach is of evolutionary and neo-Schumpeterian character, and if it has practical possibilities of enriching these modern analyses, it seems that we can answer affirmatively.

\section{Acknowledgement}

We want to show our gratitude to Dr. Andreas Andrikopoulos, Associate Professor at the Department of Business Administration of the University of the Aegean, who provided useful comments during the writing of this manuscript.

\section{References}

Acemoglu, D., \& Robinson, J. A. (2012). Why nations fail: The origins of power, prosperity, and poverty. New York, US: Crown Publications. https://doi.org/10.1111/dpr.12048

Andersen, E. S. (2009). Schumpeter's evolutionary economics: A theoretical, historical and statistical analysis of the engine of capitalism. London; New York: Anthem Press.

Aydin, D. G., \& Takay, B. A. (2012). The role of competition in the techno-economic paradigm on the market. Economic Annals, 57(193), 137-150. https://doi.org/10.2298/EKA1293137A

Bodrožić, Z., \& Adler, P. S. (2018). The evolution of management models: A neo-schumpeterian theory. Administrative Science Quarterly, 63(1), 85-129. https://doi.org/10.1177/0001839217704811

Boulding, K. (1978). Ecodynamics: A new theory of societal evolution. Beverly Hills; London: Sage Publications.

Ciote, C. S. (2011). From Schumpeter to Neo-Schumpeterianism. Journal of Academic Research in Economics, 3(3), 418-424.

Cooke, P. (2016). The virtues of variety in regional innovation systems and entrepreneurial ecosystems. Journal of Open Innovation: Technology, Market, and Complexity, 2(3), 13. https://doi.org/10.1186/s40852-016-0036-x

Cordes, C. (2014). The application of evolutionary concepts in evolutionary economics (Working Paper No. 1402). Papers on Economics and Evolution.

Courvisanos, J., \& Mackenzie, S. (2014). Innovation economics and the role of the innovative entrepreneur in economic theory. Journal of Innovation Economics Management, 14(2), 41-61. https://doi.org/10.3917/jie.014.0041 
Dopfer, K. (2011). The origins of meso economics: Schumpeter's legacy and beyond. $\begin{array}{llll}\text { Journal of Evolutionary } & \text { Economics, 22(1), }\end{array}$ https://doi.org/10.1007/s00191-011-0218-4

Dosi, G. (1982). Technological paradigms and technological trajectories. Research Policy, 11(3), 147-162. https://doi.org/10.1016/0048-7333(82)90016-6

Douma, S. W., \& Schreuder, H. (2017). Economic approaches to organizations. Harlow, UK; New York, US: Pearson.

Erixon, L. (2016). Is firm renewal stimulated by negative shocks? The status of negative driving forces in Schumpeterian and Darwinian economics. Cambridge Journal of Economics, 40(1), 93-121. https://doi.org/10.1093/cje/beu068

Faissal Bassis, N., \& Armellini, F. (2018). Systems of innovation and innovation ecosystems: A literature review in search of complementarities. Journal of Evolutionary Economics, 28(5), 1053-1080. https://doi.org/10.1007/s00191-018-0600-6

Freeman, C. (2009). Schumpeter's business cycles and techno-economic paradigms. In E. S. Reinert, W. J. M. Drechsler, C. Perez, \& R. Kattel (Eds.), Techno-economic paradigms: Essays in honour of Carlota Perez (pp. 125-144). London; New York; Delhi: Anthem Press India. https://doi.org/10.7135/UPO9781843318224.010

Freeman, C. (1995). The "national system of innovation" in historical perspective. Cambridge Journal of Economics, 19(1), 5-24.

Georgescu-Roegen, N. (1971). The entropy law and the economic process. Cambridge, MA: Harvard University Press. https://doi.org/10.4159/harvard.9780674281653

Gomes, L. A. de V., Facin, A. L. F., Salerno, M. S., \& Ikenami, R. K. (2018). Unpacking the innovation ecosystem construct: Evolution, gaps and trends. Technological Forecasting and Social Change, 136, 30-48. https://doi.org/10.1016/j.techfore.2016.11.009

Gómez-Uranga, M., Miguel, J. C., \& Zabala-Iturriagagoitia, J. M. (2014). Epigenetic economic dynamics: The evolution of big internet business ecosystems, evidence for patents. Technovation, 34(3), 177-189. https://doi.org/10.1016/j.technovation.2013.12.004

González-Loureiro, M., Dabic, M., \& Cvijanović, V. (2011). Keynesian, post-Keynesian versus Schumpeterian, neo-Schumpeterian: An integrated approach to the innovation theory. Management Decision, 49(2), 195-207. https://doi.org/10.1108/00251741111109115

Gutiérrez-Barbarrusa, T. (2019). The interpretation of the cyclical history of capitalism. A comparison between the neo-Schumpeterian and social structure of accumulation (SSA) approaches in light of the long wave theory. Journal of Evolutionary Economics, 29(4), 1285-1314. https://doi.org/10.1007/s00191-019-00631-0

Hanusch, H., \& Pyka, A. (2005). Principles of Neo-Schumpeterian economics (No. 278). Universitaet Augsburg, Institute for Economics. 
Hart, N. (2013). Marshall, evolutionary economics, and post-Keynesian theory. In N. Hart, Alfred Marshall and modern economics: Equilibrium theory and evolutionary economics (pp. 157-180). London: Palgrave Macmillan. https://doi.org/10.1057/9781137029751_8

Heinrich, T. (2017). The narrow and broad approaches to evolutionary modeling in economics. Journal of Economic Issues, 51(2), 383-391. https://doi.org/10.1080/00213624.2017.1320912

Hodgson, G. (1993). Economics and evolution: Bringing life back into economics. Cambridge: Polity Press. https://doi.org/10.3998/mpub.14010

Hodgson, G. (1994). Precursors of modern evolutionary economics: Marx, Marshall, Veblen, and Schumpeter. In R. England (Ed.), Evolutionary concepts in contemporary economics (pp. 9-35). Ann Arbor, MI: The University of Michigan Press.

Hodgson, G. (1998). Competence and contract in the theory of the firm. Journal of Economic Behavior \& Organization, 35(2), 179-201. https://doi.org/10.1016/S0167-2681(98)00053-5

Hodgson, G., \& Lamberg, J.-A. (2018). The past and future of evolutionary economics: Some reflections based on new bibliometric evidence. Evolutionary and Institutional Economics Review, 15(1), 167-187. https://doi.org/10.1007/s40844-016-0044-3

Kaldor, M. (2008, October 31). Crisis as prelude to a new Golden Age. Retrieved September 14, 2019, from https://www.opendemocracy.net/en/crisis-as-prelude-to-a-new-golden-age/

Köhler, J. (2012). A comparison of the neo-Schumpeterian theory of Kondratiev waves and the multi-level perspective on transitions. Environmental Innovation and Societal Transitions, 3, 1-15. https://doi.org/10.1016/j.eist.2012.04.001

Levinthal, D. (2006). The Neo-Schumpeterian theory of the firm and the strategy field. Industrial and Corporate Change, 15(2), 391-394. https://doi.org/10.1093/icc/dt1004

Lundvall, B.-Å. (1992). National Innovation Systems: Towards a theory of innovation and interactive learning. London: Pinter Publishers.

Malecki, E. J., \& Spigel, B. (2017). Innovation and entrepreneurship. In The Elgar companion to innovation and knowledge creation (pp. 625-637). Cheltenham, UK: Edward Elgar Publishing. https://doi.org/10.4337/9781782548522.00050

Marshall, A. (1890). Principles of Economics. London: Macmillan.

Metcalfe, J. S. (2010). Complexity and emergence in economics: The road from Smith to Hayek (via Marshall and Schumpeter). History of Economic Ideas, 18(2), 45-75.

Moore, J. (1993). Predators and prey: A new ecology of competition. Harvard Business Review, 71(3), 75-86.

Nelson, R. R. (Ed.). (1993). National innovation systems: A comparative analysis. New York: Oxford University Press. 
Nelson, R. R. (2018). Economics from an evolutionary perspective. In R. R. Nelson (Ed.), Modern evolutionary economics: An overview (pp. 1-34). Cambridge, UK: Cambridge University Press. https://doi.org/10.1017/9781108661928.001

Nelson, R. R., \& Winter, S. G. (1982). An evolutionary theory of economic change. Cambridge, MA; London, UK: The Belknap Press of Harvard University Press.

Perez, C. (2002). Technological revolutions and financial capital: The dynamics of bubbles and golden ages. Cheltenham, UK: Edward Elgar. https://doi.org/10.4337/9781781005323

Perez, C. (2010). Technological revolutions and techno-economic paradigms. Cambridge Journal of Economics, 34(1), 185-202. https://doi.org/10.1093/cje/bep051

Rahmeyer, F. (2010). A neo-Darwinian foundation of evolutionary economics. With an application to the theory of the firm (No. 309). Universitaet Augsburg, Institute for Economics.

Rahmeyer, F. (2016). Schumpeter, Marshall, and Neo-Schumpeterian evolutionary economics. Jahrbücher Für Nationalökonomie Und Statistik, 233(1), 39-64. https://doi.org/10.1515/jbnst-2013-0105

Robert, V., \& Yoguel, G. (2016). Complexity paths in neo-Schumpeterian evolutionary economics, structural change and development policies. Structural Change and Economic Dynamics, 38, 3-14. https://doi.org/10.1016/j.strueco.2015.11.004

Scazzieri, R. (2018). Structural dynamics and evolutionary change. Structural Change and Economic Dynamics, 46, 52-58. https://doi.org/10.1016/j.strueco.2018.03.007

Schumpeter, J. (1931). The present world depression: A tentative diagnosis. The American Economic Review, 21(1), 179-182.

Schumpeter, J. (1939). Business cycles: A theoretical, historical and statistical analysis of the capitalist process. New York; London: McGraw-Hill.

Schumpeter, J. (1941). Alfred Marshall's principles: A semi-centennial appraisal. The American Economic Review, 31(2), 236-248.

Schumpeter, J. (1942). Capitalism, socialism and democracy (Edition published in the Taylor \& Francis e-Library, 2003). New York; London: Harper \& Brothers.

Schumpeter, J. (1946). John Maynard Keynes 1883-1946. The American Economic Review, 36(4), 495-518.

Schumpeter, J. (1949a). The Communist Manifesto in sociology and economics. Journal of Political Economy, 57(3), 199-212. https://doi.org/10.1086/256806

Schumpeter, J. (1949b). Vilfredo Pareto (1848-1923). The Quarterly Journal of Economics, 63(2), 147-173. https://doi.org/10.2307/1883096

Schumpeter, J. (1954). History of economic analysis (Edition published in the Taylor \& Francis e-Library, 2006). New York: Oxford University Press. 
Schumpeter, J. (1934). The theory of economic development: An inquiry into profits, capital, credit, interest, and the business cycle (R. Opie, Trans.). Cambridge, MA: Harvard University Press.

Sledzik, K. (2013). Knowledge based economy in a Neo-Schumpeterian point of view. Equilibrium. Quarterly Journal of Economics and Economic Policy, 8(4), 67-77. https://doi.org/10.12775/EQUIL.2013.027

Teece, D. J. (2016). Dynamic capabilities and entrepreneurial management in large organizations: Toward a theory of the (entrepreneurial) firm. European Economic Review, 86, 202-216. https://doi.org/10.1016/j.euroecorev.2015.11.006

Veblen, T. (1898). Why is economics not an evolutionary science? The Quarterly Journal of Economics, 12(4), 373-397. https://doi.org/10.2307/1882952

Vlados, Ch. (2004). La dynamique du triangle stratégie, technologie et management: L'insertion des entreprises grecques dans la globalisation (Thèse de doctorat de Sciences Économiques, Université de Paris X-Nanterre). Retrieved from http://www.theses.fr/2004PA100022

Vlados, Ch. (2005). The insertion of Greek firms into globalization: The dynamics of the triangle of strategy, technology and management. Presented at the Managing Global Trends and Challenges in a Turbulent Economy, University of the Aegean, Department of Business Administration. https://doi.org/10.2139/ssrn.3218009

Vlados, Ch. (2006). The dynamics of globalization and the Greek enterprises. Athens: Kritiki

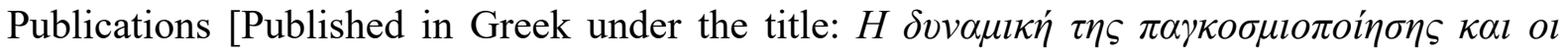
$\varepsilon \pi \imath \chi \varepsilon \imath \rho \dot{\sigma} \sigma \varepsilon \imath \varsigma \sigma \tau \eta v E \lambda \lambda \alpha \dot{\alpha} \delta \alpha$.

Vlados, Ch. (2019). On a correlative and evolutionary SWOT analysis. Journal of Strategy and Management, 12(3), 347-363. https://doi.org/10.1108/JSMA-02-2019-0026

Vlados, Ch., \& Chatzinikolaou, D. (2019a). Business ecosystems policy in Stra.Tech.Man terms: The case of the Eastern Macedonia and Thrace region. Journal of Entrepreneurship, Management and Innovation, 15(3), 163-197. https://doi.org/10.7341/20191536

Vlados, Ch., \& Chatzinikolaou, D. (2019b). Crisis and entrepreneurship in Greece: Present, past and evolving trends. Presented at the $6^{\text {th }}$ International Conference on Applied Economics "INSTITUTIONS \& THE KNOWLEDGE ECONOMY," Volos, Greece.

Vlados, Ch., \& Chatzinikolaou, D. (2019c). Crisis, institutional innovation and change management: Thoughts from the Greek case. Journal of Economics and Political Economy, 6(1), 58-77. https://doi.org/10.1453/jepe.v6i1.1854

Vlados, Ch., \& Chatzinikolaou, D. (2019d). Methodological redirections for an evolutionary approach of the external business environment. Journal of Management and Sustainability, 9(2), 25-46. https://doi.org/10.5539/jms.v9n2p25 
Vlados, Ch., Deniozos, N., \& Chatzinikolaou, D. (2019). Global crisis and restructuring: Theory, analysis, and the case of Greece. KSP Books. Retrieved from http://books.ksplibrary.org/978-605-7602-89-3/

Vlados, Ch., Deniozos, N., Chatzinikolaou, D., \& Demertzis, M. (2018a). Conceptual misunderstandings in the structuration of anti-crisis economic policy: Lessons from the Greek case. Journal of Governance and Public Policy, 5(3), 283-322. https://doi.org/10.18196/jgpp.53100

Vlados, Ch., Deniozos, N., Chatzinikolaou, D., \& Demertzis, M. (2018b). Towards an evolutionary understanding of the current global socio-economic crisis and restructuring: From a conjunctural to a structural and evolutionary perspective. Research in World Economy, 9(1), 15-33. https://doi.org/10.5430/rwe.v9n1p15

Witt, U. (2014). The future of evolutionary economics: Why the modalities of explanation matter. Journal of Institutional Economics, 10(4), 645-664. https://doi.org/10.1017/S1744137414000253

\section{Notes}

Note 1. In particular, he explores the Stra.Tech.Man physiology of samples of Greek firms in particular industries and spatial entities and finds that their majority has and "exploits" a "monadocentric" physiology and not a "massive" or "flexible" physiology. According to this particular typology, Vlados suggests that all firms exhibit the following generic attributes:

- "Monadocentric" physiology: in the sphere of management, these firms are limited to their practical experience. In the sphere of technology, they articulate mostly sporadic choices and uncoordinated, while their main strategic "logic" is based on instinctive decisions by using as a "systematization criterion" the personal inspiration deriving mostly from the business owner.

- The "massive" type of physiology corresponds to a strict specialization in the sphere of management. These firms use an incremental and linear way of exploiting their technology, while in their strategy, they rarely deviate from a mechanistic efficiency and productivity. Therefore, this particular type of firm is mostly attached to "formalism" by using economies of scale intensively.

- "Flexible" firms base their activities on extensive participation in the sphere of management. In the sphere of technology, it seems that they are capable of assimilating an increasing complexity, while in the sphere of strategy they exploit an evolutionary and historical logic that allows planning their strategic steps through a "correlative" rather than an absolute and unhistorical identification of their strengths and weaknesses (Vlados, 2019).

Note 2. For example, a "monadocentric" firm cannot display a flexible technological physiology. 


\section{Copyright Disclaimer}

Copyright for this article is retained by the author(s), with first publication rights granted to the journal. This is an open-access article distributed under the terms and conditions of the Creative Commons Attribution license (http://creativecommons.org/licenses/by/3.0/). 